\title{
Nurturing Inclusive Education through Cooperative Learning as Pedagogical Approach at Primary School Level
}

\author{
Muhammad Shahid Farooq* \\ Iqra $\operatorname{Asim}^{* *}$
}

\begin{abstract}
Inclusive education is a way of reducing exclusion and increasing participation in such a way that responds effectively to the diverse needs of all learners without differentiating on the basis of their weaknesses and strengths. This approach with the use of cooperative learning strategies provides an ample opportunity to learners by developing a sense of community where their voices are heard and responded. This qualitative inquiry was planned to look at prospects of cooperative learning instructional strategies to foster inclusion in the learning environment. The main objective of this study was to examine students' success through cooperative learning instructional strategies that are conducive to foster inclusion in the classroom. Data were collected from seven highly experienced teachers of inclusive schools by using purposive sampling technique. Participants were provided fair chance to share their belief and experiences aligned with the topic of cooperative learning for inclusion. The findings indicated that teachers use Co-op, Co-op, Numbered Heads Together, Social Skills Training and Jigsaw techniques for students on IEPs (individualized education plans) to create cooperative learning environment that is conducive to inclusive education. It is recommended that training sessions and workshops should be organized for teachers to assist them in effective implementation of cooperative learning approach. To gain more generalizable results, the study may be conducted by using quantitative approach as well.
\end{abstract}

Keywords: Inclusive education, cooperative learning approach, individualized education plans (IEPs).

\footnotetext{
*Associate Professor, Institute of Education and Research University of the Punjab, Lahore. Email: shahid.ier@pu.edu.pk,drshahid.ier@gmail.com

${ }^{* *}$ Scholar, Institute of Education and Research, University of the Punjab, Lahore.
} 


\section{Introduction}

The alienation and isolation of our society in the $20^{\text {th }}$ century moved in the next millennium because the calamity of socialization in our schools continued unabated. Deprivation growing from lack of support and care in the school, home, and community makes student isolated, disconnected and aimless. The application of cooperative learning (CL) in the classroom has influenced the fashion of care, love and community services. Cooperative learning strategies can have an effect on students learning and thereby causes a change in society. It assumes heterogeneity emphasizes interactive learning opportunities inherent in the global workplace. Let's make our classrooms exciting, stimulating places where kids leave at the end of the day feeling better about them, about their peers and learning.

Cooperative learning (CL) structure has several benefits for students with special needs. In cooperative learning environment students with special needs feel more engaged and comfortable in comparison to the traditional classroom environment. Specially, in inclusive classroom that use cooperative learning strategies, students have ample opportunities to articulate their thoughts freely, engage in questioning technique, and receive constructive feedback and additional practices on skills. Teacher can better assess the students' performance individually as well as in groups, and able to provide feedback according to their individual needs (Emerson, 2016).

The idea of inclusive education gained international attention when nations of the world gave the idea of "Education for All" in 1990 at conference in Thailand. Inclusive education policy has its roots from 1994 at Salamanca conference that challenged all schools, educators and nations to provide free access to quality education for all learners including students with special needs. Inclusive education is required to keep special education students in general educational stream and brining the support services sources to the learner, rather than taking learner to the sources for support services. To provide social integration is one of the aims of inclusive education (David \& Kuyini, 2012).

The historical background of inclusion is based on social learning theories that provides help to learner to eradicate the hindrances in the way of their academic and social progress. Students with special needs are unable to fulfill the expectations of school and fail to learn academic concepts as well as behavioral skills. Due to their failure they feel 
incompetent and less confident academically and socially. Social learning theory given by Bandura (1986) states that cognitive and behavioral learning happen through observation, modeling and imitation to others. It focuses on reciprocal causation model that is consisting on the interaction between environment, personal factor including cognition and persons' behavior. According to this theory academic and behavioral learning takes place through modeling by others. It involves the process of attention, retention, reproduction and motivation. This theory is widely helpful for inclusion in the classroom where disable students can observe their nondisable fellows and teachers to imitate desired learning behavior. Students with special needs can be engaged in learning environment through modeling and imitating correct course of actions, thus they can easily interact and develop friendships with their peers.

Cooperative learning provides opportunities to interact with their peers and is very important for scholars such as Piaget and Vygotsky (Slavin, 2009). Life experiences and social interaction provide help to disable students to gain new knowledge easily with the help of their peers. When child with special needs feel that they can learn from their peers, they will start feeling a sense of belongingness, responsibility and satisfaction. Peer-assisted learning helps students to improve listening and communication skills (Harding, 2009).

In addition, the guided learning theory is also helpful in fostering inclusion in the classroom. According to Vygotsky (1978) the zone of proximal development (ZPD) states that through guidance and encouragement, students can achieve mastery on the concept which they don't know and find difficult to know. Through cooperative learning, more competent peer can help to less able students to learn from known to unknown concepts. According to the ZPD less able students can learn easily from their more able peers through cooperative learning strategies and gain the better understanding of the concepts. It is found that peer tutoring is an effective way of learning for students with special needs (McDuffie, Mastropieri, \& Scruggs, 2009).These theories are supportive in introducing inclusion in formal classroom. According to these theories it is cleared how learning can take place academically and socially in the inclusive classroom settings through cooperative learning strategies. According to Ntshangase, Mdikana, \& Cronk (2008) interaction among students is very much important for increased academic achievement as well as for personal development. Zone of proximal development helps to 
understand how special need students can progress academically and socially with normal students in inclusive classroom.

Traditionally, the discussions on inclusion by educators are emphasized on some students with learning disabilities which have been excluded from educational settings - do have the right to learn. However, now the concept of inclusion is focusing on how to support every child to learn and help them to become successful. UNESCO's Salamanca Statement (1994) has placed the high expectations with regard to inclusion for 92 countries that had signed the statement. Inclusion demands to revisit our existing system of education, its structural orientation, aims and objectives, educational and school policies, keeping in mind that access to regular nearby school is the basic right of every child (Halinen \& Jarvinen, 2008). According to Cox (2007) three steps needed to consider when developing equitable educational system (1) access to education (2) access to quality education (3) access to learning success.

Effective inclusion is to place all students' in general educational settings with regardless of their abilities, economic status, learning style, family structure and gender orientation. It is a group endeavor that requires the collaboration among educators, professionals, community agencies and students' families. People work cooperatively, and share their resources, responsibilities, skills, and support for students' benefits (Salend, 2001). Cooperative learning refers the use of small groups through which students maximize their learning by working together (i.e) a team based project. It is an instructional method in which students work together in order to complete assigned activity (Emmer \& Gerwels, 2002).

D. Johnson and R. Johnson (1999) introduced five essential elements of cooperative learning, needed for successful implementation. These five basic elements are: (1) Positive interdependence, that means all group members, know how to sink and swim together so, they clearly need to know the task and goals. Key of success is to having personal commitments as well as with others (2) Individual and group accountability, all members are accountable for group goals and individually every person is accountable for a fair share of their work towards the goal achievement (3) Interpersonal and small-group skills, which are required to function as part of a group. They need to know how to be motivated to provide effective leadership, decision making, trust building, and conflict management. (4) Face to face interaction requires sharing of resources, help, support, encouragement and praise to each 
other's effort in order to be successful. (5) Group processing is the free communication with each other as well as the celebration of their accomplishments. Discussions are required on goal achievement and maintenance of effective working relationship.

In cooperative learning classroom many strategies are practiced by educators to meet the needs of the learners for effective learning experiences (Emmer and Gerwels, 2002). Cooperative learning has strong empirical support. D. Johnson and R. Johnson (2000), in their extensive meta-analysis ( $\mathrm{N}=164$ studies) of eight well-established cooperative strategies, found significant achievement.

Student teams achievement divisions, in which students work together in teams to learn new material presented by the teacher (Slavin, 1990). Team Games Tournaments, throughout the week, group members help each other to gain mastery in new material. Student competes in a threeperson tournament with classmates of comparable ability from other teams to earn points for their original team (Aronson \& Patone, 1997). Co-op, Co-op, following teacher-presented material, heterogeneous teams select a topic. The topic is divided into mini topics for each individual in the group to become an "expert" on. Numbered Heads Together, is a questionasking strategy, heterogeneous groups of students are formed and then numbered 1-4. Each group is consisting on one student of high ability, two students of average ability, and one student of low ability. Social Skills Training, with peers can involve observational, antecedent, and consequent approaches e.g., group contingencies, contingent social reinforcement, peer modeling (Gresham, 1981). Jigsaw requires student to take a piece of information and teach it to their group members; each student becomes an expert on a particular aspect of a topic (Goor \& Schwenn,1993). In summary, active learning can be increased through cooperative learning structures in the classrooms for both able and less able students. Cooperative learning especially in inclusive setup is helpful for those students who need extra practices as well as constructive feedback throughout their academic and social activities. Cooperative learning strategies provide support for inclusive practices and synchronize academic and social skills development (Emerson, 2016).

Teaching in an inclusive classroom requires a variety of supports in order to function effectively. These include: additional planning time, training, additional resources and aides as well as support from the principal and other staff members. Within the provincial documents on 
individual education plans (IEPs), it is stated that teachers are expected to use "a variety of teaching and learning strategies ...peer partners, collaborative groups and cross-age tutoring" (Ministry of Education, 2000, p.13). It is essential for students on IEPs to participate in group learning, such as collaborative group work, as this form of teaching has been found to be effective in implementing the goals of inclusion (Lawther, 2015). Kaur and Arora (2014) studied the inclusive education - an integrated approach. It is assumed that we should teach children in the most inclusive environment rather than in the least restrictive environment. The aim of education is to make sure that all students should gain maximum access to knowledge, information and skills that will help them to be a productive member of society.

Another aspect that consider critical for inclusive education is the acceptance and friendship to special need children. Inclusive educational teachers have ability to promote an environment where students' cooperation, personal development, social skills and interaction with peers are strongly encouraged. It creates a safe environment where student feels comfortable and compelled to participate in classroom activities. Cooperative learning provides with instructional strategies that motivate students for more learning, and motivation leads towards high achievements (Slavin, 2014). David and Kuyini (2012) examined inclusive classroom practices on social status of students with special needs and revealed that in regular classroom, teachers' instructional strategies influenced the social skills of students with special needs. Implementations of findings showed that teacher can increase inclusion with peer interaction among students with and without disability.

Patrick (2012) found that social constructive views of cooperative learning ties students together through direct interaction. Cooperative learning is an effective strategy for maximizing social and academic learning outcomes because its central focus is on the development of positive relationships and social skills of student. It endorses the social and emotional development for wellbeing and good mental health. In another study Bucholz and Sheffler (2009) examined, a teacher creates warm inclusive environment that is favorable for working cooperatively in order to learn together. Classroom procedures, strategies, and designs are needed to consider when creating a warm inclusive environment of mutual respect and social interaction. Cooperative learning practices are helpful for creating a sense of community and positive interaction to promote inclusion. Terpstra and Tamura (2007) explored a number of interventions 
that needed to promote social interaction and skills for inclusion. These are peer mediated interventions, collaborative activities, social skills training, group affection strategies, in order to foster social skills development and inclusion in the classroom.

Bick-Harand and See-Wai (2005) observed that policy makers hold the belief that inclusion into the mainstream schools is crucial for learner who are defined as special for their personal development and future achievement. There should be cultivation of social acceptance on equal level and effective learning strategies to meet individual needs. Kemple (2004) also suggested that teachers can promote inclusive setting of classroom through classroom organization and structures. Such as structured use of curriculum materials and activities (i.e) cooperative games, social problem solving exercises, collaborative learning, role playing activities to assist the academic development and social competence. Jenkins, Antil, Wayne and Vadasy (2003) found similar results in a study of cooperative learning among students with special needs. It was founded that most of the students learn best through cooperative learning rather than traditional instructions. Students produce better work in a concrete manner when they work collaboratively. Cooperative learning provides ample opportunities to students to develop their social skills by working in peer. Peer helps student to listen, understand better, respond to questions accurately and meet the expectations of assigned work.

Extensive research data suggests cooperative learning is successful approach for maximizing learning outcomes of all students as well as their social skills development (Gillies, 2003; Johnson \& Johnson, 1994; Johnson \& Smith, 2000; Slavin, 1995; Stevens \& Slevin, 1995). Cooperative learning can help to uphold socialization and learning among students (Cohen, (1994), reading and writing can promote in middle school students (Stevens, 2003) as well as produce better results for inclusion (Jenkins, Antil, Wayne, and Vadasy, 2003). In a study by Gillies and Ashman (2000) students with their peer cooperation can better understand the difficult concepts explained by teacher and work best. Study revealed that students have higher rate of success with collaborative work rather than individual work.

Cooperative learning is instructional process in which students have to work together in order to complete project and achieve their goal (Emmer and Gerwels, 2002). D. Johnson and R. Johnson (2000), in their 
extensive meta-analysis ( $\mathrm{N}=164$ studies) of eight well- established cooperative strategies, found significant achievement. Student Teams Achievement Divisions, (Slavin, 1990), Team Games Tournaments (Aronson \& Patone, 1997), Co-op, Co-op, Numbered Heads Together, Social Skills Training (e.g. group contingencies, contingent social reinforcement, peer modeling (Gresham, 1981), and Jigsaw can also be used to teach students in a cooperative manner (Goor \& Schwenn, 1993).

Antil, Jenkins, Wayne and Vadasy (1998) reported 21 interviewed teachers' positive attitude about their use of cooperative learning. They acknowledge that it works best for some students than others. Major benefits include improved self-esteem, a safe learning environment and better classroom success rate. It was reported by teachers, the self-efficacy of special remedial students can be increased by consistently participating in collaborative learning.

The most important idea of social learning and inclusion is cooperative learning that helps children to value cooperation towards learning specific skills (i.e.) Listening and responding to others, and learning to work with non friend classmates. It is best way to grouping children who are facing problems with others so that they have to talk about their difficulties (Antil et al., 1998). According to the findings by Lisa (2013) in inclusive schools, teacher must need to create a learning environment for cooperation and promote the socialization of all students. Cooperative learning with different characteristic of student is good to develop social skills, empathy, and tolerance. So cooperative learning can be successful if the class conditioned by full participation, trust, open communication, and social balance.

A lot of work has been done on cooperative learning in general educational perspective but it is least concerned with regards to inclusive setup. In our local education system where most of the teachers are unable to make inclusion in formal classrooms, the present study was designed to consider the theoretical framework of social learning theories and guided theories to foster inclusion easily in our formal classroom setting. Teachers have to face many challenges in inclusive classrooms to engage different students in high quality learning activities. Therefore, it is very important for children with special needs to participate in cooperative learning strategies as it has been found to be effective in implementing the goals of inclusion. This study was conducted to foster inclusion through cooperative learning approach among primary graders. 


\section{Objectives of the Study}

Objectives of this study were to:

i. examine students' success through instructional strategies of cooperative learning.

ii. look at teachers' design of classroom instructional strategies that fosters the inclusion in classroom through cooperative learning.

iii. appraise that the cooperative learning approach is conducive to inclusion in classroom.

\section{Research Questions}

The research questions of this study were:

i. How do teachers design lessons by using cooperative learning strategies in such a way that are responsive to learning needs of students with and without special needs?

ii. What instructional strategies have been employed by teachers to create opportunities of inclusive environment for being responsive to students' individualized learning needs through cooperative learning?

iii. How teacher can create a warm, safe and non-discriminatory environment receptive to all students' individual needs through cooperative learning approach?

\section{Significance of the Study}

Primarily inclusive schools, teachers and students are potential beneficiaries of this study. They may benefited from this study because it replaces individual assignments and efforts with multitude techniques of cooperative learning in which students can work with small, heterogeneous and organized group rather than working in their own circles. Teachers can provide a more accommodating learning environment for students that experiences problems in learning. In an inclusive setting of classroom, the use of cooperative learning strategies can articulate students' thoughts; they can receive constructive feedback, can engage in questioning answering techniques and receive additional practices on skills that are important to become more responsive towards educational and social environment. Teachers can be benefited by gaining information on how to design individual educational plans by considering cooperative learning strategies for students with special needs to foster inclusion in classroom. 


\section{Method and Procedure}

Educators, face several social, professional and instructional problems in classrooms. This study followed qualitative approach of inquiry that is suitable in exploration of social or human problems (Creswell, 2013). It focused on the use of cooperative learning strategies for including students through IEPs by using interview techniques for documenting view of the respondents. There were limited numbers of participants in this study. Although all participants were experienced but the limited number of participants confines the generalizability of this research to the educational community as a whole. This research is delimited to barriers that may occur while implementing this approach of study in classroom.

\section{Sampling}

The population for this research consisted on the teachers of inclusive education schools of a metropolitan city of Pakistan. The target population was selected on the bases of available inclusive educational schools in which three experienced school teachers of primary grades were interviewed through open ended questions to gain insight of this study.

For this qualitative exploration purposive technique of sampling was used for selection of sample. According to Creswell (2013) purposive sampling involves selecting of participants that will best inform research questions being presented within the study. Highly experienced techers of inclusive education schools were selected that can properly explian the problem under discussion.

The interview participants were selected based on the below mentioned criteria because the experience and expertise of teachers were required who had successfully incorporated cooperative learning in their classrooms.

The following criteria was used in determining the participants for this study:

i. Five or more years teaching experience with special need students being taught through IEPs.

ii. Experience in planning cooperative learning activities that incorporate children on IEPs. 
iii. Experience in the use of cooperative learning strategies, whether they had an additional certificate or had attended workshops regarding cooperative learning.

iv. Have an additional qualification in Special Education.

v. Primary/Junior teaching qualification, either currently teaching at this level or are recently retired.

\section{Data Collecton}

Interviews were conducted by using an interview protocol to record data from targted participants about cooperative learning approach to foster inclusion in classrooms. Three participants were founded for this study and were interviewed through face-to-face, one-on-one interaction with researchers. The discussion with these selected participants regarding their experiences in using cooperative lerning approach in inclusive settings were transcribed.

The self developed interview protocol was consisted of 10 questions aligned with objectives of this study. This protocol was got validated through experts' opinion. Five experts of the field were consulted and the protocol was improved in the light of their suggestions. Each interview continued for 60 minutes and the questioned asked were:

1. How teachers make selection of students with high, average, and low ability to ask them questions to maximize their learning?

2. How teachers examine students' achievement on individual test and consider their scores in accordance with their improvement?

3. How teachers encourage students to help each other in order to enhance their own learning?

4. Which techniques teachers use to ensure accountability of students individually and in group?

5. Which techniques are used by teachers to teach interpersonal skills to students' i.e. leadership, decision making, confidence building and management of diversity?

6. How teachers motivate students to help, support, encourage each other's effort to learn?

7. How teachers provide a free, comfortable and warming environment in order to work together?

8. What teachers do to create inclusive learning environment that is equitable and non discriminatory, sensitive to all the students and relevant to everyday life of children? 
9. How teachers recognize students with diverse socio emotional, psycho linguistic, physical and cognitive abilities and differences?

10. How teachers plan their lessons in accordance with special needs of student?

\section{Analysis and Interpretation}

The transcribed data were analyzed by using thematic approach. The selected participants were the classroom teachers who were employing the instructional strategies of cooperative learning in their classrooms and had success including students with special needs in the process of learning. During the interviews, themes surrounding the topic of cooperative learning as a process of instruction for children on IEPs emerged and developed. After the data were transcribed and coded, three consistent themes had emerged:

a. Students' success through instructional strategies of cooperative learning

b. Teachers' design of classroom strategies that fosters students' inclusion and success in classroom through cooperative learning

c. Cooperative learning approach as conducive medium for inclusion in classroom.

Each theme including sub-themes is explained below in detail.

\section{Instructional strategies}

The main focus of this study was on the instructional strategies that classroom teachers use in order to facilitate cooperative learning for students on IEPs. This theme was the largest theme to emerge from the data collection during the interviews, which was expected as it is the main priority of this study. All participants discussed in depth the importance of instructional strategies of cooperative learning for successful implementation. In all interviews the following instructional strategies were mentioned and discussed in depth: Johnson and Johnson's five elements of cooperative learning are "positive interdependence, interpersonal skills, face to face interaction, individual and group accountability and group processing".

Respondent 1 was very vocal about the integration of five elements while designing instruction based on cooperative learning strategy. The participant discussed the intensive need of lesson planning after the final report is given by the team of experts after the screening of child special 
needs. First work was done on the special needs of child then teacher comes towards the academic goals of study.

To check the positive interdependence of each child, teachers use different techniques i.e. concrete objects, different technologies i.e. video clip on mobile, TV, computer etc. teachers provide them reinforcement in order to work with each other cooperatively.

Teachers use the IEPs to ensure the individual and groups accountability. According to their individual educational plan teachers assess students along with their special needs whether they need extra attention, care and planning. Different techniques are used i.e. check list, observations, formal and informal tasks etc.

According to child's IEP teacher communicate interpersonal skills to each child. Modeling and other techniques i.e. time in and time out are used to teach them leadership, decision making, confidence building and managing diversity.

To ensure face to face interaction among children during cooperative activity teachers keep eye on them, for reinforcing teacher motivate them to help, support, encourage to each other.

To ensure group processing time management is used by teachers, they provide free time to each child to work effectively in group. Teachers indirectly observes students cooperation to ensure their success and to resolve their conflicts, to minimize behavioral problems.

Respondent 2 was very much agreeing with the use of individual educational plans before designing the cooperative activities for students. Teachers were sound having the same opinion regarding the importance of five elements of instructional strategies given by Johnson and Johnson (1999). These all elements are considered carefully while designing the cooperative learning activities among normal and special students.

To promote positive interdependence modeling and role playing by teachers were mostly used. They do role play to teach them because "children like to copy their teacher". So "teacher's personality should be attractive and impressive". 
By assessing and observing their actions, behaviors and performance teacher check the individual and group accountability. Often question answer technique is used to make them aware about tasks. Teachers sit with students and work with them freely in leisure childish way.

Teachers mostly use to note taking about children's personal likes or dislikes before teaching them interpersonal and small group skills. They shape their minds according to their interest to work in group with their fellows. Teachers also use demonstrations by different technologies. While using cooperative activities, teachers continuously involve indirect and direct observation of students to ensure face to face interaction.

To check effectiveness of Group processing question answer technique is mostly used by teachers, one to one conversation, interaction with all individuals personally and by providing them extra time for learning the task mutually is also used. Game play activities, number assigning games on board are also used by teachers in order to encourage cooperative effective work among children.

Respondent 3 was also in favor of using five elements of cooperative instructional strategies while designing individual educational objectives. It is essential to follow these five basic elements in order to ensure the effectiveness and success of learning activities. Teachers mostly use grouping of student with heterogeneous abilities and be seated near them to ensure their positive interdependence and use reinforcement to maximize their success. Teachers viewed that if teachers don't have any type of accountability of student performance, the purpose of activity will destroy. So teachers mostly use individual task or assignments to assess their accountability and understandings of individual and group work.

Teachers verbally and physically prompt children to work with each other in group and ensure the interpersonal skills by teaching and observing their behaviors toward each other while engaging in task. To manage their face to face interaction teachers assign role of tutor or tutee in order to work with effective cooperation with each other.

Group processing ensured by teachers to providing free time for communication and participation with each other. Teachers motivate children to act as leader, decision maker, and guider with the help of modeling technique in classroom. 


\section{Inclusion through Cooperative Learning Designs}

All respondents have attended inclusion training sessions where they received how to create a well warming community of students where they feel safe and comfortable. They received trainings to design classroom activities to foster inclusion through individual, peer, pair as well as group learning to maximize the students' success according to their IEPs. They acclaim this inclusion practice as a helping way that enable them how to create a warming, responsive, safe and comfortable classroom community for all children.

Respondent 1explained that inclusion is a very constructive way to create a positive learning environment for all students according to their special needs. Teachers discuss how they recognize students with heterogeneous abilities and demand different educational needs. Students are passed out through a process of pre-assessment after they get admission in school. They are kept under observation for two weeks, and observed by a team of experts including psychiatrists, medical professional and special education expert. After observing a child, they send a detailed report to classroom teacher about child disabilities. By considering the important points of this report, classroom teacher design educational objectives of each child along with the help of child's parents according to the special needs of child.

Teachers use pre-established report to make group for cooperative technique of number head together in accordance with special needs of student. To teach them new material with the help of team games tournament teachers assess student from morning assembly as model in front of other students as a reinforcer. Then make group of student with mix abilities and assign them group work in order to enhance their progress.

In student teams achievement division teachers make the use of IEPs to check students achieved objectives of learning. To teach them social skills training teachers use first modeling by self then organizes peer modeling, peer assisted learning strategies and class wide peer tutoring. A number of activities i.e. blocks arrangement, modeling, computer games, video clips on tabs are used by teachers for this purpose. Teachers said "As reinforcer they mostly hug the children and play with them to make them feel safe and affectionate". Teachers reinforce them also by offering "delicious lunch" in break time. 
Respondent 2 explained that inclusion practices through cooperative leaning strategies are very essential. Teachers categorize students with the help of their IEPs with high, average and low ability and design Co-op, co-op strategy of cooperative learning. Teachers arrange number head together on the assessment of their prior knowledge and understanding about the things.

To assign new task and projects to students', teachers use team games tournament in order to learn together with each other and to encourage them work cooperatively, teachers use different reinforcer i.e. sweet candies, small gifts, oral praise and extra bonus marks. To teach them Science, English readings and Mathematics teachers mostly use reciprocal peer tutoring in order to enhance their social skills along with their academic achievements.

Respondent 3 agreed also that inclusion is vital to the cooperative learning foundations. Respondent observed immediate benefits of team building exercise in the classroom. Teachers provide equal time and opportunity to each student in order to achieve their individual educational plans. Teachers design number head together and Co-op Co-op according to individual educational plans if needed. To teach them interpersonal skills and social skills teachers use reciprocal peer tutoring, peer modeling and peer assisted learning. To reinforce students to work together teachers use extra things for lunch time, badges for student of the day to their best performance, and candies as reinforcer.

Results also show the use of classroom cooperative learning strategies that teacher can use to maximize learning success of students. Different strategies used by teachers include student teams achievement divisions, team games tournaments, co-op, co-op, numbered heads together, group contingencies, contingent social reinforcement, peer modeling, reciprocal peering etc. literature also supports the use of cooperative learning approach by the use of these strategies. 


\section{Cooperative Approach is Conducive to Inclusion}

When the use of cooperative learning approach was discussed with all participants of this study, they immensely showed the importance of IEPs to understand the special needs of each child. They strongly agreed to establish a clear set of specific students learning outcomes and objectives to design learning activities that maximize their success academically and non-academically. Through the use of cooperative learning, students gained valuable life skills that they could use in future.

Respondent 1 discussed that, to achieve the objectives of IEPs teachers use self-modeling first, then engage students in peer tutoring, peer modeling and assess the need to change or re-establish the strategies if objective is not achieved. To assess students' self-understanding and knowledge that they gain through cooperative learning, teacher assesses them outside the formal settings of classroom and ensures the generalizability of cooperative learning among special students.

Teachers also write report; arrange teacher parent meetings to ensure students' performance and success. Teachers collect information about students' family background and design activities that are equitable, nondiscriminatory and sensitive to all students and create a warming atmosphere of classroom. As it is said by respondent "Parents are called on fruits celebration day, to send children with fruits who can afford easily, then parents with high SES are requested to send more fruits for those whom can't afford. Teacher personally brings fruits for children whose parents cannot afford, so manages an equal and nondiscriminatory environment of classroom. Respondent remains in contact continuously with child's parents through mobile phone and messaging to gain information about students' performance at home as well to create inclusive environment for them".

Respondent 2 explained the importance of inclusion through cooperative learning. Teachers acclaim the importance of peer and group learning to enhance the confidence of students in daily life. Teachers find parent and colleagues helping and participating to assess a set of specific students learning outcomes whether achieved or need to work more on them.

Teachers notice student's behavior, their cognitive skills and understandings in and outside the classroom which they learn in group work. Teachers mostly use concrete objects to eliminate diversity among 
students. As said by respondent "I used red or white balls, asked students how they look beautiful either separate or mixed? They replied mixed as they view red and white color looks beautiful with each other, thus by concrete examples, tried to explain them to work beautifully, effectively with those who are not able to work alone".

Respondent 3 said that having an inclusive classroom through cooperative approach, students feel safe, confident and their learning flourishes. Teachers discuss that they have a clearly stated list of objectives, students on IEPs would benefit from the strengths of others and also enhance their own learning. As respondent said "students understand better and quickly when they learn with peer". Sometimes they cannot cope with teachers but they understand the concept of mathematics effectively with the help of peer. Teachers make group of students with heterogeneous abilities to overcome the diversity in the classroom, and reinforce them to work with each other friendly. For this purpose, teachers also celebrate different days as Independence Day, color day, and rewards day to maximize the student's diversities and also celebrate importance of different students' cultural, occupational background information to reduce diversity and increase participation of them.

It is founded by results; Cooperative learning approach is conducive to inclusion, where student finds a warm, caring, safe and nondiscriminatory atmosphere to their needs. Bucholz and Sheffler (2009) examined, a teacher creates warm inclusive environment that is favorable for working cooperatively in order to learn together. Kaur and Arora (2014) also assumed that teachers should teach children in the most inclusive environment rather than in the least restrictive environment. It creates a safe environment where students feel comfortable and compelled to participate in classroom activities. Cooperative learning provides with instructional strategies that motivate students for more learning, and motivation lead towards high achievements (Slavin, 2014). Kemple (2004) also suggested that teachers can promote inclusive settings of classroom by classroom organization and structures; as specialized use of instructional materials and activities "cooperative games, social problem solving exercises, collaborative learning, role playing activities' to assist the academic development and social competence". Cooperative learning strategy can help to uphold socialization and learning of children (Cohen, 1994), reading and writing can promoted in elementary school level students (Stevens, 2003) as well as produce favorable results for including children (Jenkins, Antil, Wayne, \&Vadasy, 2003). 


\section{Discussion}

This study was set out to answer the question: how are teachers designing lesson using cooperative learning strategies in such a way that include and are responsive to the educational needs of students on individual educational plans in mainstream classroom? The answer that researchers received from the completion of this study immensely effect that the instructional strategies a teacher wish to employ in the classroom provides multitude of academic and social benefits i.e. increase students' achievement scores, motivation, decision making power, leadership ability, trust building, self-confidence, self efficacy and conflict management. By using cooperative learning strategy for inclusion, teachers can provide students with opportunity to share their ideas and understanding with their peers in a non discriminatory and comfortable classroom environment.

The main purpose of this study was to identify the cooperative learning strategies that teachers can use to foster inclusion in classroom. Both literature review and findings presented in this research paper indicated numerous cooperative learning strategies that can be used successfully to foster inclusion (i.e. co-op, co-op, number heads together, students teams achievement division, jigsaw, class wide peer tutoring, reciprocal peer tutoring, peer assisted learning strategies and peer modeling). Cooperative learning is an instructional method in which students work together in groups in order to complete an activity and results are also consistent with previous researches (Johnson \& Johnson, 1999; Emmer \& Gerwels, 2002).

Johnson and Johnson's (1999) five basic elements of cooperative learning were at the core of both the literature review and discussions made by participants that they used in their classroom. It is very important for children on IEP 's to participate in group learning, such as collaborative group work, as this form of teaching has been found to be effective in implementing the goals of inclusion (Lawther, 2015).

The results of this study indicates that use of cooperative learning strategies in the classroom of student on IEPs provide an ample opportunity to each student to work and learn with their peers. In a study by Gillies and Ashman (2000) students who work together collaboratively, help their peers to understand a concept. Bick-Harand and See-Wai (2005) observed that policy makers hold the belief that inclusion into the main stream schools is crucial for learner who are defined as special for their personal development and future achievement. There should be cultivation 
of social acceptance on equal level and effective learning strategies to meet individual needs.

A result of this study shows that cooperative learning has numerous benefits i.e. increase classroom participation, motivation, self-confidence, self-esteem, and maximize development of academic and social skills of students with and without special needs (Gillies, 2003; Terpstra and Tamura, 2007).

\section{Conclusion}

The findings of this study are concluded that the importance of cooperative learning approach to integrate the students on IEPs in a mainstream classroom to work and learn effectively in order to be successful in their daily life. Teachers use Co-op, Co-op, Numbered Heads Together, Social Skills Training and Jigsaw technique to create cooperative learning environment that is conducive to academic and social progress of all students. All strategies of cooperative learning ties cognitive, social, emotional and attitudinal learning's that are contributing towards inclusion in the classroom. The use of cooperative learning strategies in the classroom of students on IEPs provides ample opportunities to each student to work and learn with their peers successfully. Cooperative learning has numerous benefits i.e. increase classroom participation, motivation, self-confidence, self-esteem, and maximize growth of academic and social skills of students with and without special needs. Cooperative learning approach is founded conducive to inclusion, where student finds a warm, caring, safe and nondiscriminatory atmosphere to their needs where voices of each and every student are heard and given importance.

\section{Recommendations}

The use of instructional strategy i.e. cooperative learning is not possible to implement successfully without gaining the understanding of its components. So teacher should know the mechanism of cooperative learning before using this instructional strategy. There should be training sessions and workshops for teachers to assist them for the successful implementation of this approach especially for children with special needs. The classroom environment should be designed in such a way, where all students feel valued, respected and heard. Individual and group accountability by teachers should be ensured at every step of cooperative learning. Teachers need to make sure about the students' understanding who are on individual education plans (IEPs) and make them aware about their specific role and accountability within group. 


\section{References}

Aronson, E., \& Patone, P. (1997). The jigsaw classroom: Building cooperation in the class-room. Menlo Park, CA: Longman.

Antil, L. R., Jenkins, J. R., Wayne, S. K., \& Vadasy, P. F. (1998). Cooperative learning: Prevalence, conceptualizations, and the relation between research and practice. American Educational Research Journal, 35(3), 419-454.

Bandura, A. (1986). Social foundations of thought and action: A social cognitive theory. Englewood Cliffs, NJ, US: Prentice-Hall, Inc.

Jenkins, J. R., Antil, L. R., Wayne, S. K., \&Vadasy, P. F. (2003). How cooperative learning works for special education and remedial students. Exceptional Children, 69(3), 279-292.

Bucholz, J. L., \& Sheffler, J. L. (2009).Creating a warm and inclusive classroom environment: Planning for all children to feel welcome. Electronic Journal for Inclusive Education, 2(4), 4.

Bick-Harand, L., \& See-Wai. (2005). Inclusion or exclusion?-A study of Hong Kong students' affective and social outcomes in a mainstream classroom. Educational Research for Policy and Practice,4(3), 145-167.

Cohen, E. G. (1994). Restructuring the classroom: Conditions for productive small groups. Review of Educational Research, 64(1), 1-35.

Creswell, J. W. (2013). Achieving integration in mixed methods designs, principles and practices. Health Services Research, 48(6), 2134-2156.

Cox, C. (2007). Inclusive education and inclusive society. What can we do and promote from the educational systems? Presentation at the international workshop on inclusive education, Latin America, Argentina.

David, R., \& Kuyini, A. B. (2012). Social Inclusion: Teachers as facilitators in peer acceptance of students with disabilities in regular classrooms in Tamil Nadu, India. International Journal of Special Education, 27(2), 157-168.

Emmer, E. T., \& Gerwels, M. C. (2002). Cooperative learning in elementary classrooms: Teaching practices and lesson characteristics. The Elementary School Journal, 103(1), 75-91. 
Emerson, T. L. (2016). Cooperative learning and personality types. International Review of Economics Education, 21(2), 21-29.

Goor, B., \& Schwenn, O. (1993). Accommodating diversity and disability with cooperative learning. Intervention in School and Clinic,29(1), 6-16.

Gresham, F. M. (1981). Social skills training with handicapped children: A Review of Educational Research, 51(1), 139-176.

Gillies, R. M., \& Ashman, A. F. (2000). The effects of cooperative learning on Students with learning difficulties in the lower elementary school. The Journal of Special Education, 34(1), 19-27.

Gillies, R. M. (2003). Structuring cooperative group work in classrooms. International Journal of Educational Research, 39(2), 35-49.

Halinen, I., \& Jarvinen, R. (2008). Towards inclusive education: The case of Finland. Prospects, 38(1), 77-97.

Harding, S. (2009). Successful inclusion models for students with disabilities require strong site leadership: Autism and behavioral disorders create many challenges for the learning environment. International Journal of Learning, 16(3), 91-103.

Johnson, D. W. (1994). Cooperative learning in the classroom. Association for Supervision and Curriculum Development, $1250 \mathrm{~N}$. Pitt St., Alexandria, VA 22314.

Johnson, D. W., \& Johnson, R. T.(1999). Making cooperative learning work. Theory into Practice,38(2), 67-73.

Johnson, D. W., \& Johnson, R. T. (2000). Cooperative learning, values, and culturally plural classrooms. Classroom Issues: Practice, Pedagogy and Curriculum, 38(3), 15-28.

Jenkins, J., Antil, L., Wayne, S., \&Vadasy, P.(2003). How cooperative learning works for special education and remedial students. Exceptional Children, 69(3), 279-292.

Terpstra, J. E., \& Tamura, R. (2008). Effective social interaction strategies for inclusive settings. Early Childhood Education Journal, 35(5), 405-411. 
Kemple, K. M. (2004). Let's be Friends: Peer competence and social inclusion in early childhood programs. New York: Teachers College Press.

Kaur, J., \& Arora, B. (2014). Inclusive education-an integrated approach. International Journal of Research in Humanities, Arts and Literature, 2(2), 59-64.

Lisa, M.(2013). Teacher attitudes and behavior toward the inclusion of children with social, emotional and behavioral difficulties in mainstream schools: An application of the theory of planned behavior. Teaching and Teacher Education, 29(1), 46-52.

Lawther, S. (2015). Fostering inclusion through cooperative learning. A research paper Ontario Institute for Studies in Education of the University of Toronto.

McDuffie, K., Mastropieri, M., \& Scruggs, T. (2009). Differential effects of peer tutoring in co-taught and non-co-taught classes: Results for content learning and student-teacher interactions. Council of Exceptional Children, 75(4), 493-510.

Ntshangase, S., Mdikana, A., \& Cronk, C. (2008). A comparative study of self-esteem of adolescent boys with and without learning disabilities. International Journal of Special Education, 23(2), 75-84.

Slavin, R. E. (1990). Research on cooperative learning: Consensus and controversy. Educational Leadership, 47(4), 52-54.

Slavin, R. E. (1995). Effects of a cooperative learning approach in reading and writing on academically handicapped and non-handicapped students. The Elementary School Journal, 95(3), 241-262.

Slavin, R. E. (1996). Research on cooperative learning and achievement: What we know, what we need to know. Contemporary Educational Psychology, 21(1), 43-69.

Slavin, R. (2009). Educational psychology: Theory and practice (9th ed.). Upper Saddle River, New Jersey: Pearson Education, Inc. 
Slavin, R. E. (2014). Cooperative learning and academic achievement: why does group work? Anales de Psicología, 30(3), 785-791.

Stevens, R. J., \& Slavin, R. E. (1995). Effects of a cooperative learning approach in reading and writing on academically handicapped and non handicapped students. The Elementary School Journal, 95(3), 241-262.

Salend, S. J. (2001). Creating instructional rubrics for inclusive classrooms. Teaching Exceptional Children, 34(2), 8-13.

Stevens, R.(2003). Student team reading and writing: A cooperative learning approach to middle school literacy instruction. Educational Research and Evaluation, 9(2), 137-160.

Vygotsky, L. S. (1978). Mind in society: The development of higher psychological processes. Cambridge, MA: Harvard University Press.

\section{Citation of this Article:}

Farooq, M. S., \& Asim, I. (2018). Nurturing inclusive education through cooperative learning as pedagogical approach at primary school level. Pakistan Journal of Education, 35 (3), 163-186. 